ISSN 2078-6441. Вісник Львівського університету. Серія географічна. 2013. Випуск 42. С. 290-297. Visnyk of the Lviv University. Series Geography. 2013. Issue 42. P. 290-297.

$551.435 .4+552.08$

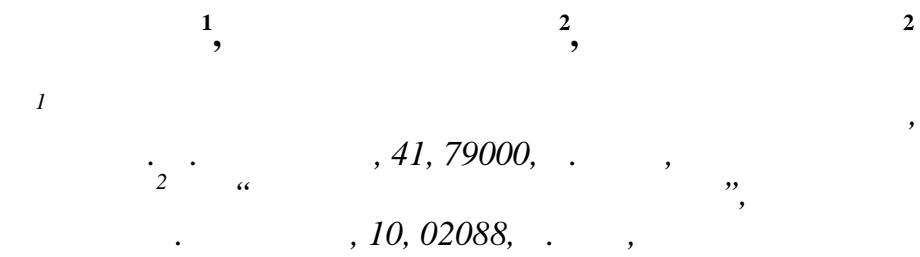

ечовинний скл д четвертинних н копичень н території олинського олісся вивчений недост тньо. е стосується і кумуляцій льодовикового комплексу. озглянуто д ні з мінер логії льодовикових т водно-льодовикових ос дів і петрогр фічного скл ду їхньої грубоул мкової скл дової. зн чено про можливість використ ння м тері лу для розшуків нетр диційних н олинському оліссі корисних коп лин.

лючові слов : олинське олісся, дніпровське зледеніння, будівельні м тері ли, лм з, піроп, бурштин, фосф тні пісковики, с мородне золото.

с дові утворення гляці льного комплексу н олинському оліссі ( ) зд вн були об'єктом підвищеного інтересу перш з все як порівняно легкодоступне місцеве джерело будівельних м тері лів (піски, піщ но-гр війні суміші, суглинки тощо).

поч тком проведення в північно-з хідному регіоні кр їни пл номірних геологічних знім нь (60-ті роки ст.) відкл ди льодовикового комплексу вивч ли головно з позиції їх прид тності як будівельної сировини. ілянки розвитку гляці льних порід, які з речовинними і фізико-мех нічними вл стивостями відповід ли інструктивно регл ментов ним будівельним п р метр м, оконтурюв ли в родовищ 3 підр хов ними з п с ми і вр ховув лися у відповідних к д стр х.

розуміло, що зрост ння обсягів будівництв житл, доріг т інших об'єктів потребує з лучення зн чної кількості будівельної сировини, це призводить до висн ження відомих родовищ і зумовлює необхідність поповнення з п сів 3 вдяки дет ліз ції їхніх фл нгів і вивчення інших ділянок. тже, пит ння, пов'яз ні з будівельними м тері л ми, зосередженими в геологічних тіл $\mathrm{x}$ приповерхневого 3 ляг ння, зокрем гляці льних, є тр диційними і з вжди кту льними. роте перелік корисних коп лин, приурочених до ділянок л тер льного розвитку льодовикових і водно-льодовикових утворень, беручи до ув ги всі н явні результ ти геологорозвідув льних робіт, можн поповнити т кими вид ми, як лм з, бурштин, фосфорити, золото т ін.

йв жливіші геотектонічні елементи олинського олісся - північно-з хідний схил кр їнського щит ( ) i рип'ятський в л-уже пон д півстоліття розгляд ють як одні з н йприв бливіших об'єктів для виявлення в їхніх меж х родовищ лм зів, пов'яз них передусім з їхніми кімберлітовими і л мпроїтовими джерел ми. ьогодні н території виділено ухотсько- ольську площу, високі перспективи якої н відкриття корінних лм зоносних порід визн чені н явністю ул мків м нтійних утворень у своєрідних брекчіях, приурочених до розломних порушень, т кож

(C) енд ., осовський ., теюк ., 2013 
н явністю в них лм зів і мінер лів-супутників лм зів ( $)$. н хідки т ких мінер лів відомі т кож у відкл д х нижньої крейди, що перекрив ють брекчійов ні інтерв ли [4]. новішими д ними, деякі з брекчій цієї площі, “... можн вв ж ти кр терними ф ціями ді трем лужно-ультр основного скл ду, що з зн ли вторинних змін” [7, с. 74]. цьому р зі зроблено висновок, що породи н леж ть до л мпроїтової форм ції.

підст ві зн хідок у брекчіях ул мків верхньосилурійських порід вік формув ння брекчій визн ч ють як постсилурійський (н йвірогідніше девонський). місними для них є докембрійські породи поліської (рифей), волинської і могилів-подільської (венд) серій. тже, 6 з льні горизонти нижньокрейдового розрізу слугують н йпершими i н йбільш інформ тивними колектор ми ул мкового м тері лу в р зі руйнув ння і переміщення (перенесення) лм зовмісних утворень. ізніші колектори є як вторинні, проміжні, причому п леогенові т неогенові тр пляються н території , з огляду н їхне розмив ння, фр гмент рно, четвертинні здебільшого вміщують перевідкл дений м тері л, зокрем, лм зи і з усіх р нніх вікових рівнів.

явні результ ти кернового і шліхового опробув ння четвертинних відкл дів, проведеного в різні роки геолог ми івнічгеологія (тепер “ки їнськ геологічн комп нія") свідч ть про лм зоносність четвертинного покриву, у тому числі його льодовикових ф цій. ідповідн інформ ція розпорошен по різних виробничих звіт х, уз г льнен х р ктеристик і неб г тьох виявлених лм зів ст ном н 2004 р. н веден в колективній моногр фії [4]. в ж ємо з доцільне коротко н д ти інформ цію стосовно зн хідок лм зів у відкл д х дніпровського клім толіту т генетично пов'яз них з ними більших н гром джень із вл сною інтерпрет цією геоморфологічної позиції і літолого-ф ці льних особливостей вмісних порід.

св. 1424 в інтерв лі 3,0-3,5 м (проб 1) у різнозернистих гр велистих глинистих піск х, які вміщують ул мки кременів і гр нітоїдів, виявлено ул мок крист л лм зу розміром 0,2×0,28 мм. л мок кут стої форми, із сильним лм зним блиском; для рельєфу гр ней х р ктерн східч ст поверхня з прим зК ми білого кольору. птично ізотропний, пок зник $з$ ломлення н б г то перевищує 1,980. ля інших проб х р ктерн підвищен кількість піропу фіолетового кольору, в пробі 1 - му с ніту. енетично піски розгляд ли як флювіогляці льні утворення н сипної кінцевої морени, у н шій інтерпрет ції це відкл ди поперечного флювіок му.

ерно лм зу виявлено в шліховій пробі м сою 8,1 кг, відібр ної з коси висотою до 0,8 м н д урізом води н лівому березі р. тир у р йоні с. римне. тері л проби пісок дрібнозернистий, сл бко глинистий. овнішній вигляд зерн - кубічний б г тогр нник із тригон льними виступ ми. ерно зеленкув того кольору. оверхні гр ней шорсткув ті, розміри - 0,27×0,25×0,25 мм. птично нізотропний, люмінесценції нем . ля проби х р ктерний підвищений вміст піропу. ісце відбору проби є в долині p. тир у з фронт льній (проксим льній) ч стині комплексу кінцевих морен н пірного і н сипного генезису в $\mathrm{p}$ йоні смт ф лівк .

шліховій пробі 724 м сою 41,5 кг, відібр ній з борту однієї з к н в, що з'єднують p. тохід із оз. юбязь, у 1976 р. виявлено дв ул мки крист лів лм зу. ерн безколірні, непр вильної форми, розмір ми $0,15 \times 0,1 \times 0,1$ і $0,2 \times 0,08 \times 0,07$ мм. ля проби х р ктерн зн чн кількість зерен піропу. тері л проби - пісок середньодрібнозернистий, є продуктом розмиву p. рип'ять 3 фронт льних гляці льних т флювіогляці льних утворень другої постм ксим льної ( оловнянсько- уцинської) 
ст дії, кр йові форми якої поширені вздовж лівого берег р. тохід н південний з хід від смт юбешів.

ункти цих зн хідок розт шов ні в меж х порівняно добре дослідженої ухотськоольської площі, н сході , тоді як ступінь вивченості пит нь лм зоносності зони зчленув ння рип'ятського в лу 3 олинським п леозойським підняттям зн чно нижчий. ому зн хідки лм зів, н н шу думку, треб вв ж ти суттєвим досягненням i в жливим кроком у н прямі вияснення б г тьох розшуково-прогнозних спектів лм зоносності , зокрем , і ролі у цьому гляці льних процесів.

ерший “ш цький” лм з виявлено в середньо-крупнозернистих піщ них відкл д х пляжу оз. ісочне 2002 р. в шліховій пробі об’ємом близько 5 л з декільк метрів від берег [14]. ещо пізніше після ретельнішого вивчення цієї ж проби зн йдено ще п'ять крист лів лм зу [15], під ч с повторного опробув ння (проб 60 літрів) відшук ли ул мок подібного крист л [16].

рист ломорфологічні і деякі в жливі фізичні (фото- і рентгенолюмінесценція) особливості крист лічних індивідів лм зів д ють підст ву пов'язув ти їхнє походження з кімберлітовими бо л мпроїтовими структур ми. иявлені лм зи з розмір ми є в меж х фр кції +0,5-1,0 мм. редст влені вони прозорими, безколірними, близькими до ізометричних (окт едричний бо перехідний, окт едр-ромбододек едр г бітус) індивід ми без жодних озн к обк т ності [16]. икон ний н ми н ліз польових м тері лів д $є$ змогу зробити висновок про можливість з числення лм зовмісних ос дів до з ндрових пісків другої постм ксим льної ст дії дніпровського зледеніння.

роведення в незн чних обсяг х дод ткового шліхового опробув ння приозерних відкл дів уздовж берегової лінії поблизу місцезн ходження лм зів, т кож з підстильного донного м тері лу (ручне буріння глибиною до 1,5 м) не д ло нових зн хідок крист лів, проте з г лом підтвердило д ні стосовно речовинного скл ду вмісних порід, отрим ні попередник ми [2, 11]. прикл д, 3-поміж мінер лів легкої фр кції тут домінують кв рц (до 92,6 \%) і к лієві польові шп ти (до 12,6\%), у в жкій перев ж ють гр н ти, ільменіт, ст вроліт, епідот, рогов обм нК, топ 3, турм лін т ін.

зв’язку з лм зоносністю з зн чимо про н явність у відкл д х льодовикового комплексу н всій території мінер лів, які тр диційно н леж ть до (піропи, хромшпінеліди, хромдіопсиди, пікроільменіти).оч ці тр пляються т кож в ос д х нижнього плейстоцену, все-т ки н йбільш їхня концентр ція і л тер льн поширеність з фіксов н в утвореннях дніпровського горизонту. йч стіше зн ходять піропи, можливо, з огляду н їхню порівняно легку візу льну ді гностику. іропи в меж х розвитку льодовикових відкл дів р йону м ють зн чні в рі ції вмістів хрому і к льцію, проте чітко вир жених ореолів н йв жливіших різновидів лм зної соці ції (високохромисті кнорингітові), як і високохромистих шпінелідів, у меж х не виявлено. е можн пояснюв ти з г лом сл бкою н літичною вивченістю їхніх типохімічних особливостей, відсутністю дет ліз ції виявлених н перших ст діях розшуків пунктів їхніх зн хідок, безкерновим бурінням деяких свердловин по четвертинних відкл д х, що було зумовлене орієнт цією розшуків н відкриття корінного родовищ лише домезозойського віку. тже, з ур хув нням різного підходу до вивчення типіз цію і повноцінне порівняння просторово розрізнених їхніх зн хідок викон ти пр ктично неможливо.

еред гляці льних форм дніпровського віку н йсприятливішими для виявлення підвищених концентр цій i лм зу є н сипні кінцеві морени, ози, флювіо- т флювіо-лімногляці льні к ми. н чн ч стин м тері лу ос дів цього горизонту, як 
основного пост ч льник теригенної скл дової в меж х льодовикової зони , н явн i в скл ді п чок відкл дів люві льного й озерного походження середньоверхньоплейстценового віку, що т кож можуть уміщув ти лм з і супутні мінер ли в ном льних для регіону кількостях. одібні підвищені вмісти лм зу в льодовикових відкл д х формуються з г лом з вдяки екз р ції його високопродуктивних корінних джерел бо вторинних колекторів, оскільки постійне привнесення ззовні без лм зоносного м тері лу призводить до розубожув ння розсипних корисних скупчень. роте можливо, що вн слідок інтенсивного перемив ння т лими льодовиковими вод ми вл сне льодовикових утворень н віть у вип дк х їхньої убогої лм зоносності 3 сприятливих умов можуть формув тися дост тньо зб г чені розсипи [5]. уже дин мічний перебіг процесів ерозії $\mathrm{T}$ кумуляції в русл $\mathrm{x}$ потоків із льодовиковим живленням, який у декільк р зів вищий, ніж у “норм льних" флюві льних систем х [18], т кож х р ктер цих процесів, пов'яз ний з сезонними т добовими ритм ми бляції, свідч ть про небезпідст вність т кого погляду.

лм зоносні геологічні тіл льодовикового генезису відомі в б г тьох $\mathrm{p}$ йон х д вніх пл тформ ( івнічно мерик нськ, фрик но- р військ, ибірськ , ндост нськ , встр лійськ , хідноєвропейськ ), проте опис ні недост тньо дет льно для того, щоб сформув ти більш-менш чітке уявлення щодо джерел їхнього утворення, д льності тр нспортув ння ул мкового м тері лу, умов н гром дження і збереження продуктивних покл дів. кл сифік ціях розсипних родовищ лм зів [5] як окремий вирізнено льодовиковий генетичний тип з вл сне льодовиковим і водно-льодовиковим підтип ми, які, відповідно, м ють пл щоподібний і лінійний морфологічні типи розсипищ, зокрем , і промислового зн чення. Звич й т кі родовищ з середніми вміст ми крист лів н леж ть до бідної (менше $0,2 \mathrm{k}$ р т / ${ }^{3}$ ), зрідк до

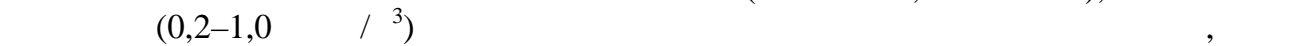
яких водно-льодовиковий підтип вирізняється дещо вищими концентр ціями і вміст ми ювелірних відмін.

озсипні прояви лм зів тр пляються у різновікових ос дових гляцігенних пород х від докембрійських до голоценових $[1,3,5,8,9]$, і методик їхнього виявлення досить різном нітн й з лежить від низки чинників. прикл д, використовують методи розшуків 3 зн хідк ми лм зів, 3 , фокусно-гляці льний метод [6]. ост нні 10-15 років з'явилося більше інформ ції про кімберлітовий м гм тизм н дського щит , який в спекті проблем, що розгляд ємо, ст новить зн чний інтерес. собливо це стосується кімберлітів промислового зн чення геоструктурної обл сті лейв, відкритої 1991 p. ( івнічно- хідні території н ди). геоморфологічного і гідрогр фічного поглядів ця обл сть (кімберлітов субпровінція) відрізняється від р йонів розміщення сибірських кімберлітових родовищ. е вирівнян пл топодібн поверхня 3 гіпсометричними позн чк ми 200-350 м н д рівнем моря, приблизно н 60-70\% перекрит системою озер, пр ктично без великих водотоків і виходу н денну поверхню крист лічних порід рхею, що прорв ні трубк ми і д йк ми кімберлітів верхньоп леозойського i крейдово-п леогенового віку. йки не з зн в ли зн чного впливу ерозійноденуд ційних процесів і перекриті лише льодовиковими відкл д ми [8]. ількість відкритих трубч стих тіл досяг є кількох десятків, більш їхня ч стин розт шов н під озер ми. пр ці [9] як прикл д опис но одне з т ких озер глибиною 50 м, утворене в контурі трубки під дією льодовик , що виор в (до 30 м) менш стійкі породи верхньої ч стини, 3 хопивши зб г чений м тері л. йоптим льнішими утвореннями для лок ліз ції корисного компонент (льодовиковий літодин мічний тип ореолів, 3 
кл сифік цією [1]) є донні морени й ози. н дські спеці лісти не зн йшли великої різниці між зі шліхів, відібр них поряд з трубкою і н відст ні 600 км від неї в б сейні p. ккензі, проте з фіксув ли зменшення (до 100 р зів) їхньої кількості.

думку 6 г тьох дослідників, четвертинні відкл ди льодовикового комплексу $€$ м лоінформ тивними щодо проблем лм зоносності з огляду н привнесення ул мкового м тері лу з відд лених джерел європейської півночі. роте н явні тут i лм зи могли походити і з місцевих різновікових профілів. прикл д, у північно-східній ч стині виявлено ф кти з ляг ння порід нтропогену в меж х долин льодовикового виорюв ння вн слідок повної екз р ції утворень п леогенкрейдового віку безпосередньо н утвореннях волинської серії. ідповідно, існув ли (і існують) ділянки повної бо ч сткової денуд ції т симіляції н йв жливішого, як ув ж ють, льб-сеном нського колектор лм зоносних м с. м тері л ми відтворення п леогеогр фічних і літолого-ф ці льних умов формув ння відкл дів верхнього льбу т сеном ну в меж х ухотської площі зроблено висновок про вулк нічну природу деяких з н явних у той ч с островів, які слугув ли корінним джерелом з фіксов них тут [10]. снують різні припущення і щодо д леко не ордин рних зн хідок лм зу в р йоні цьких озер, проте їх т к чи ін кше тр ктують як похідні концепції місцевого їхнього джерел [13-16].

огляду н 3 р женість льодовикових відкл дів олинського олісся і вл сне лм з ми, принципов зд тність яких у розшуково-прогнозних цілях доведен в інших регіон х світу, н суч сній ст дії вивчення лм зної проблеми треб розгляд ти цю територію в р нзі об'єкт з невизн ченими перспектив ми, який потребує довивчення. обто необхідне якомог дет льніше відтворення особливостей дольодовикового рельєфу (вектори н прямів руху льодовикових язиків, х р ктер і глибин їхніх врізів тощо), відтворення в зн чно більших обсяг х (пон д 250-300 лм зів) відомих зн хідок і опробув ння н лм зи нових потенційно перспективних гляцігенних площ і розрізів. підст ві історії формув ння речовинного скл ду м тері лу ос дів четвертинного покриву т особливості геологічної будови лож , с ме - н явності відкл дів п леогену, льодовикові відкл ди, особливо північно-східної ч стини урія- тохідського, північних ч стин тохід- тирського т тир- оринського межиріч, окрім лм зоносних, треб розгляд ти і як потенційно бурштиноносні.

ро н явність бурштину у водно-льодовикових відкл д х н території олинського олісся вперше з зн чив . утковський, який включив розсипи цього типу до групи “ер тичних". крім нього, про бурштиноносність ос дів плейстоцену пис в . риговський [17]. ьогодні бурштин виявлено н зн чній території олинського олісся від долини р. урія н 3 ході до р. оринь н сході, н прикл д, у відкл д х великих м ргін льних флювіогляці льних олицько- олодимирецького т убівськоідринського конусів винесення т в ос д х внутрішніх убровицької, очулищенської, итвицької і ережницької з ндродельт [12].

ромислових концентр цій бурштину в флювіогляці льних відкл д х олинського олісся поки що не виявлено. в ж ючи н н явність т ких відкл дів у північній ч стині лтійсько- ніпровської бурштиноносної провінції н території імеччини т ольщі, розсипи бурштину подібного типу треб очікув ти і н терен х івнічнохідної кр їни. дн к спеці лізов них робіт з вивчення відкл дів льодовикового ряду регіону щодо проявів бурштину не проводили. віть убогі прояви бурштину в подібних ос д х можуть слугув ти в жливим критерієм для розшуків бг тих корінних розсипів у пород х п леогену. ро в жливість розшуків бурштину в льодови- 
кових відкл д х свідчить той ф кт, що в р зі перенесення зберіг ються н йбільш цінні ювелірні різновиди бурштину [12].

еред інших корисних компонентів, якими можуть бути зб г чені четвертинні відкл ди , н звемо н явність у їхньому петрогр фічному скл ді включень зн чної кількості жовен фосф тних пісковиків, імовірно, п леогенового віку. в ж ючи н особливості седимент ції нторопогену , концентр ції фосф тів, прид тних для промислової розробки, досить цік вими є н сипні кінцеві морени т флювіок ми, особливо з н явності в скл ді флювіок мів грубозернистих відкл дів. прикл д, у меж $\mathrm{x}$ тнівського родовищ жовнових фосфоритів у водно-льодовикових ос д $\mathrm{x}$ відк ртов ні покл ди з вміст ми $25,7 \%$, які в комплексі з п леогеновими відкл д ми є промисловими об'єкт ми.

собливий інтерес з огляду н дніпровські відкл ди з г лом як джерело м тері лу для озерних відкл дів є н явність у них поодиноких зн ків с мородного золот [2, 11], які, проте, сьогодні ст новлять лише мінер логічний інтерес.

тже, н території олинського олісся у відкл д х льодовикового комплексу виявлені не тільки родовищ будівельних м тері лів, й прояви інших видів корисних коп лин, визн чення пр ктичної зн чимості яких потребує под льших конкретних орг ніз ційних зусиль і скоординов них дій з цік влених ф хівців.

1. $\phi н$ сьев . . оисков я минер логия лм 3 / . . фн сьев, . . инчук, . . охиленко - овосибирск : ео, 1998. - 602 с.

2. урзель . . ещественный сост в современных ос дков цких озёр / . . урзель, . . оповч к, . . ценко [и др.] // естник ьвов. ун-т . ер. геол. - 1982. - ып. 8. - . 36-59.

3. влов . п проблеме формиров ния позднеп леозойских лм зоносных россыпей отуобинского р йон / . . влов, . . шик, . . Зилов // учные методы прогнозиров ния, поисков и оценки месторождений лм зов: тез. докл. IV сесоюз. совещ ния, г. имферополь, 13-15 м я 1980 г. - овосибирск, 1980. - . 118-119.

4. ерспективы коренной лм зоносности кр ины / [ . . ейко, . . урский, . . Ыков и др.]. - иев; ьвов : ентр вропы, 2006. - 223 с.

5. рокопчук . . лм зные россыпи и методик их прогнозиров ния и поисков / . . рокопчук - . : едр , 1979. - 248 с.

6. косырев. . екоторые спекты методов поисков и экономики лм зоносных месторождений з рубежом / . . косырев // учные методы прогнозиров ния, поисков и оценки месторождений лм зов: тез. докл. IV сесоюз. совещ ния, г. имферополь, 13-15 м я 1980 г. - овосибирск, 1980. - . 174-176.

7. $\quad$ скко. . труктурно-тектонічні, мінер логічні т геохімічні особливості брекчій ухотсько- ерек льської ділянки / . . р ско, . . риходько, . . теюк // оренные и россыпные месторождения лм зов и в жнейших мет ллов: междун р. н уч.-пр кт. конф., г. имферополь. - имферополь, 2008. $.72-74$.

8. ркив . . стория лм 3 / . . ркив, . . инчук, . . уев. - . : ук , 1998. -602 c. 
9. ркив . . оренные месторождения лм зов мир / . . ркив, . . инчук, . . рючков - . : едр , 1998. - 555 с.

10. мелівський . . леогеогр фічний i літолого-ф ці льний н ліз крейдових відкл дів івнічної олині в зв’язку з розшук ми родовищ лм зів / . . мелівський, . . тхей // існик ьвів. ун-ту. ер. геол. - 1999. ип. 14. - .94-105.

11. мелівський . . інер лого-геохімічн х р ктеристик суч сних відкл дів цьких озер / . . мелівський, . . остюк, . . p нов [т ін.] // цьке поозер'я: х р ктеристик біотичних і біотичних компонентів екосистем. - ьвів : вросвіт, 2008. - . 47-79.

12. овкопляс . нт рь в неоплейстоценовых отложениях олынского олесья / . овкопляс, . цуй, . оляник, . ристофоров // ляці л і перегляці л олинського олісся : м тері ли укр.-пол. семін ру, цьк, 11-15 вересня 2005 р. - ьвів : ид вничий центр імені в н р нк , 2005. - . 231-239.

13. ценко . . ро проблеми лм зоносності північно-з хідної території кр їни / . . ценко, . . влюк, . . ценко // інер льні ресурси кр їни. - 2003. № 4. - . 13-16.

14. иенко . . б лм зоносности недр олыни (форм ционно-минер генический спект) / . . ценко, . . ценко, . . влюк // борник н учных р бот институт геохимии окруж ющей среды к и ып. 11, . 2. - . 100-106.

15. ценко . . 6 лм зоносности терригенных форм ций олыни / . . ценко, . . урский, . . ценко [т ін.] // інер льні ресурси кр їни. $-2006 .-$ № 1. . 10-12.

16. ценко . рист ломорфологія, фізичні особливості т походження ді м нтів 3 прибережних пісків озер н хідній олині / . ценко, . екеш , . олошиновський [т ін.] // інер л. зб. - 2011. - № 61, вип. 1-2. - . 79-88.

17. Krygowski B. Zarys geologiczno-morfologiczny południowego Polesia / B. Krygowski. Poznań, 1947. - S. 1-139. - (Pozn. Tow. Prz. Nauk, Pr. Kom. Matem.-przyrodn.).

18. Włodarski $W$. Jednostki facialne, środowiskowe a geomorfologiczne w obrębie glacialnych systemów depozycyjnych / W. Włodarski // Osady, struktury deformacyjne I formy warciańskiej strefy glacjomarginalnej na Nizinie Podlaskiej. Warsztaty terenowe. Lublin-Mielnik, 25-29 września 2000 r. Materiały. - Lublin, 2000. - S. 76-79. 


\title{
QUATERNARY SEDIMENTS OF GLACIAL SERIES OF VOLHYN POLISSIA AS A SOURCE OF MINERAL RESOURCES
}

\author{
Andriy Renda ${ }^{1}$, Yaroslav Kosovski², Volodymyr Matejuk ${ }^{2}$ \\ ${ }^{1}$ Ivan Franko National University of Lviv, \\ P. Doroshenko Str., 41, UA - 79000 Lviv, Ukraine \\ ${ }^{2}$ State Enterprise "Ukrainian Geological Company", \\ Geophysics lane, 10, UA-02088 Kyiv, Ukraine
}

Material composition of Quaternary sediments in the Volhyn Polissia studied enough. The same applies to the accumulation of deposits of glacial complex. Data of mineralogy of glacial and fluvioglacial sediments and their petrographic composition of coarse fragment component was considered. The possibility of using of the material for search of non-traditional mineral deposits in Volhyn Polissya was noted.

Key words: Volhyn Polissia, Dnieper glaciation, building materials, diamond, pyrope, amber, phosphate sandstone, native gold.

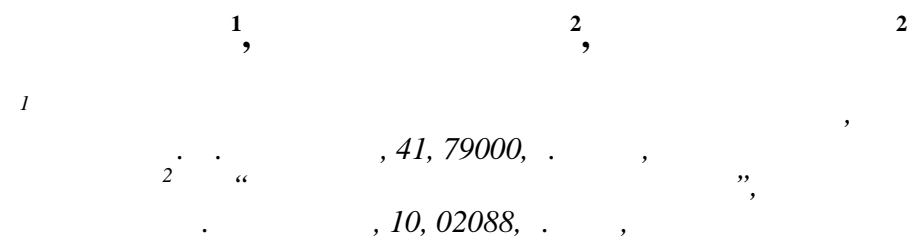

ещественный сост в четвертичных н коплений н территории олынского олесья изучен недост точно. то к с ется и ледниковых ккумуляций. ссмотрено д нные по минер логии отложений днепровского горизонт и петрогр фическому сост ву их грубообломочной сост вляющей. к 3 но н присутствие в их сост ве лм 3 , янт ря, с мородного золот, фосф тных песч ников. дел но выводы о недост точном изучении м тери льного сост в нтропоген олынского олесья, и ледниковых отложений в ч стности. к 3 но н возможность использов ния их не только к к строительного м тери л, но и для поисков нетр диционных для отложений ледникового ряд полезных ископ емых.

лючевые слов : олынское олесье, днепровское оледенение, строительные м тери лы, лм з, пироп, янт рь, фосф тные песч ники, с мородное золото. 